\title{
CAN PREHYDRATION WITH DIFFERENT FLUIDS OR APPLIED MUSGLE TENSION PREVENT OR ATTENUATE ADVERSE EFFECTS IN BLOOD DONORS?
}

\author{
Amatya $M$
}

Department of Physiology, Nepal Medical College Teaching Hospital, Attarkhel, Gokarneshwor-8, Kathmandu, Nepal

\begin{abstract}
Adverse effects (AE) like vasovagal reactions (presyncope and syncope) have negative impact on old as well as new blood donors. Various methods have been suggested to prevent or attenuate AE in blood donors. This study assessed the effectiveness of prehydration with different fluids or applied muscle tension (AMT) during blood donation in preventing or attenuating AE. Consenting and eligible voluntary blood donors $(n=448)$ were randomly allocated to Control $(n=115)$, prehydration with 500 $\mathrm{mL}$ plain water (PW, $\mathrm{n}=97$ ), prehydration with oral rehydration solution (ORS, $n=71$ ), prehydration with $400 \mathrm{~mL}$ fruit juice (FJ, $\mathrm{n=74}$ ), or leg muscle tensing during blood removal (AMT, $\mathrm{n}=91$ ) groups. Donors' hemodynamic responses to blood donation were assessed by comparing blood pressures (systolic-SBP and diastolic-DBP) and heart rate (HR) recorded before blood removal to values midway during, and at $0 \mathrm{~min}, 5 \mathrm{~min}, 10 \mathrm{~min}$ and $15 \mathrm{~min}$ after blood removal. Presyncope and syncope were defined by BP and HR changes. Subjective AE were also recorded. Overall, 35 donors (7.8\%) suffered AE with highest rates in PW (13.4\%) and ORS (11.3\%) groups and lowest in Control (3.5\%) although group differences were not significant ( $p>0.05$, Chi square). Blood removal was associated with significant falls in SBP and DBP (mean falls by 6.63 and $3.35 \mathrm{mmHg}$, respectively; $\mathrm{p}<0.001$ ) but an insignificant rise in HR (mean increase by $0.67 \mathrm{bpm}, \mathrm{p}>0.05$ ). Hemodynamic responses showed significant differences between groups $(\mathrm{p}<0.001$, repeated measures ANOVA). Therefore, role of the interventions in relation to $\mathrm{AE}$ in blood donors could not be established.
\end{abstract}

\section{KEYWORDS}

Adverse effects, applied muscle tension, blood donation, prehydration, presyncope, syncope.

\section{CORRESPONDING AUTHOR}

Dr. Mrigendra Amatya

Associate Professor,

Department of Physiology,

Nepal Medical College,

Gokarneswor-8, Kathmandu, Nepal

Email: amatyam01@gmail.com

Orcid ID: 0000-0002-0312-3220

DOI: https://doi.org/10.3126/nmcj.v22i1-2.30034 


\section{INTRODUCTION}

Blood donation is a generally safe procedure. However, a small pecentage of donors may experience adverse effects (AE). ${ }^{1,2}$ Various factors are found to be associated with increased risk for such events, mostly non-modifiable, such as age, sex, weight and number of past donations. ${ }^{2}$ Incidences of adverse reactions have significant effects on the return behavior of the donors. More the number and severity of adverse reactions, less is the likelihood for donors to return for donation. ${ }^{3,4}$ As a result, efforts are made to reduce the incidence of AE related to blood donation. The common methods are ingestion of plenty of fluid before blood donation (prehydration) and muscle tensing exercises during blood donation. ${ }^{5-8}$ Prehydration technique is also commonly used in other hypotensive situations such as postural orthostatic hypotension and exercise conditions, and with various types of fluid. ${ }^{9-11}$ Different methods including different types of fluid have not been reported to be tested in a single study and in field settings of blood donation.

\section{MATERIALS AND METHODS}

The study was conducted from May 2014 to April 2015 at the Central Blood Transfusion Services (CBTS), Exhibition Road, Kathmandu which is the national and referral center for blood transfusion services in Nepal. The study was approved by the Institutional Review Committee of Nepal Medical College, Kathmandu. Permission was also obtained from the CBTS for conducting the study. Informed written consent was obtained from all the participants.

Donors were selected by the standard eligibility screening criteria and clinical examination. Poorly prepared donors such as inadequate sleep, not had meal for more than 6 hours and anxiety were excluded. By lottery method, they were randomly allocated into five experimental groups -no intervention (Control), three prehydration groups, and applied muscle tension group (AMT). Prehydration groups consumed $500 \mathrm{~mL}$ of plain drinking water (PW group), $500 \mathrm{~mL}$ of freshly prepared oral rehydration solution (ORS group), or $400 \mathrm{~mL}$ of fruit juice (FJ group) about 20 minutes before blood removal (phlebotomy). Control and AMT groups took rest for the 20 minutes before phlebotomy. Heart rate (HR) and blood pressures (BP, systolic-SBP and diastolicDBP) were measureed at the time of recruitment and after 20 minutes waiting period just before phlebotomy.

Phlebomoty was performed with adequate precautions from the median cubital vein with the donor in comfortable semi-inclined position. Amount of blood removed varied from 300-450 $\mathrm{ml}$, according to patient requirement and donor characteristics such as body build.

In the AMT group, as soon as phlebotomy was in place, muscle tensing exercise was started on cues from an assistant. The lower limb muscles were tensed moderately and slowly (in 5 seconds) to just straighten and lift them slightly off the bed. After about 5 seconds, the muscles were slowly relaxed and the limbs were rested on the bed. After 5 seconds of rest, again muscle tensing was started, followed by relaxation. The maneuver was stopped after blood removal was complete. Other groups did not do anything particular during blood removal.

Parameters measured/recorded: BP and HR were recorded from the non-donating arm. HR was measured by taking pulse rate of the radial artery (beats per minute, bpm). BP was recorded by auscultatory method at the time of recruitment (baseline), just before, about midway during and immediately after $(0 \mathrm{~min})$ blood removal and regularly up to 20 minutes of post-donation observation period (at $5 \mathrm{~min}, 10 \mathrm{~min}, 15 \mathrm{~min}$ and $20 \mathrm{~min}$ ). However, as most donors did not stay for 20 minutes, analysis was made for up to 15 minutes only.

Donors were regularly asked if they felt any discomfort (subjective adverse effects) and to report as early as possible. Close monitoring was done to detect and treat $\mathrm{AE}$ at the earliest. Syncope was defined as a condition of transient loss of consciousness; clinically it was defined as SBP less than $70 \mathrm{mmHg}$ and/or HR less than 50 $\mathrm{bpm}$. Presyncope was defined as a condition of fall in SBP by $\geq 30 \mathrm{mmHg}$ with concommittant fall in HR by $\geq 10 \mathrm{bpm}$, or a fall in HR by $\geq 30 \mathrm{bpm}$ with a concomittant fall in SBP by $\geq 10 \mathrm{mmHg} .{ }^{5}$

Data management and statistics: Microsoft Excel was used for primary data entry and constructing graphs; SPSS 16.0 was used for statistical analyses. Group differences were determined by Chi square or ANOVA, as applicable. A p value $<0.05$ was considered significant for all comparisons.

\section{RESULTS}

A total of 448 voluntary donors were studied who were randomly allocated into five experimental groups-97 in PW, 71 in ORS, 74 in FJ, 91 in AMT and 115 in Control (Fig. 1).

The sample included 388 males and 60 females; the donors' age (years completed) ranged from 17 to 54 years. The groups were not significantly different for distribution of gender, age, height, 


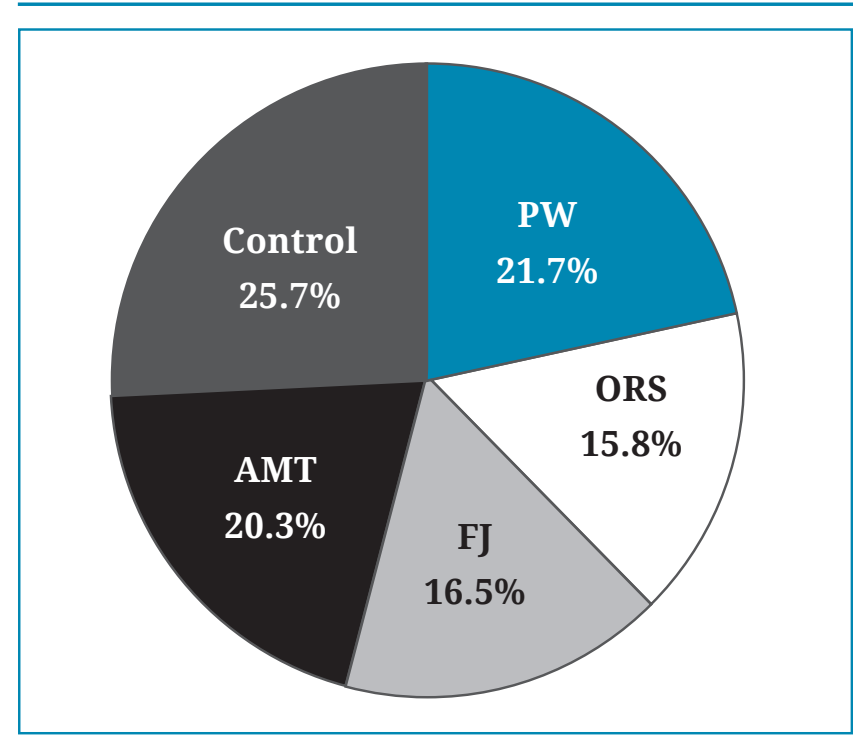

Fig. 1: Distribution of donors in different experimental groups $(\mathrm{N}=448)(\mathrm{PW}=$ plain water, ORS = oral rehydration solution, $\mathrm{FJ}$ = fruit juice, $\mathrm{AMT}=$ active muscle tension)

weight, body mass index, and number of past donations (Table 1)

The groups were comparable for baseline SBP and DBP values but differed for HR (Table 2). The FJ and AMT groups had higher HR compared to rest of the groups.

Overall, there was a decline in blood pressure with blood removal which steadied towards later parts of the observation time whereas HR mostly remained at a level comparable to intial values (Fig. 2). Both SBP and DBP falls (mean decreases of $6.6 \mathrm{mmHg}$ and $3.35 \mathrm{mmHg}$, respectively) were highly significant $(p<0.001)$ but the HR change was insignificant (mean increase by $0.67 \mathrm{bpm}$, $\mathrm{p}>0.05)$.

However, there were remarkable inter-group differences in the changes in these parameters (Table 3). For all three parameters, the patterns of responses were significantly different among the groups.

Changes in blood pressure: From the values before blood removal, there was a continuous fall in SBP in all groups. This fall was most pronounced in ORS and PW and least in FJ and AMT groups. SBP continued to fall in the post-donation period in the ORS but mostly stabilized in other groups (Fig. 3). Likewise, DBP also decreased in all groups in the post-donation period. The DBP fall was especially marked in the ORS and Control groups and least in the PW and AMT groups (Fig. 4).

Heart rate changes: The HR changes were not uniform in different donor groups (figure 5). HR steadily decreased in the FJ and AMT groups at all measurements. In the other groups, HR elevated during blood removal and remained at higher levels in the post-donation period. Highest degree of rise in HR was shown by the ORS group.

Occurrence of adverse effects: Three types of $\mathrm{AE}$ were recorded - subjective (complained by the donor), presyncope (detected by measurements of SBP and HR), and syncope (observed as transient loss of consciousness or marked fall in SBP). The commonest adverse effects complained

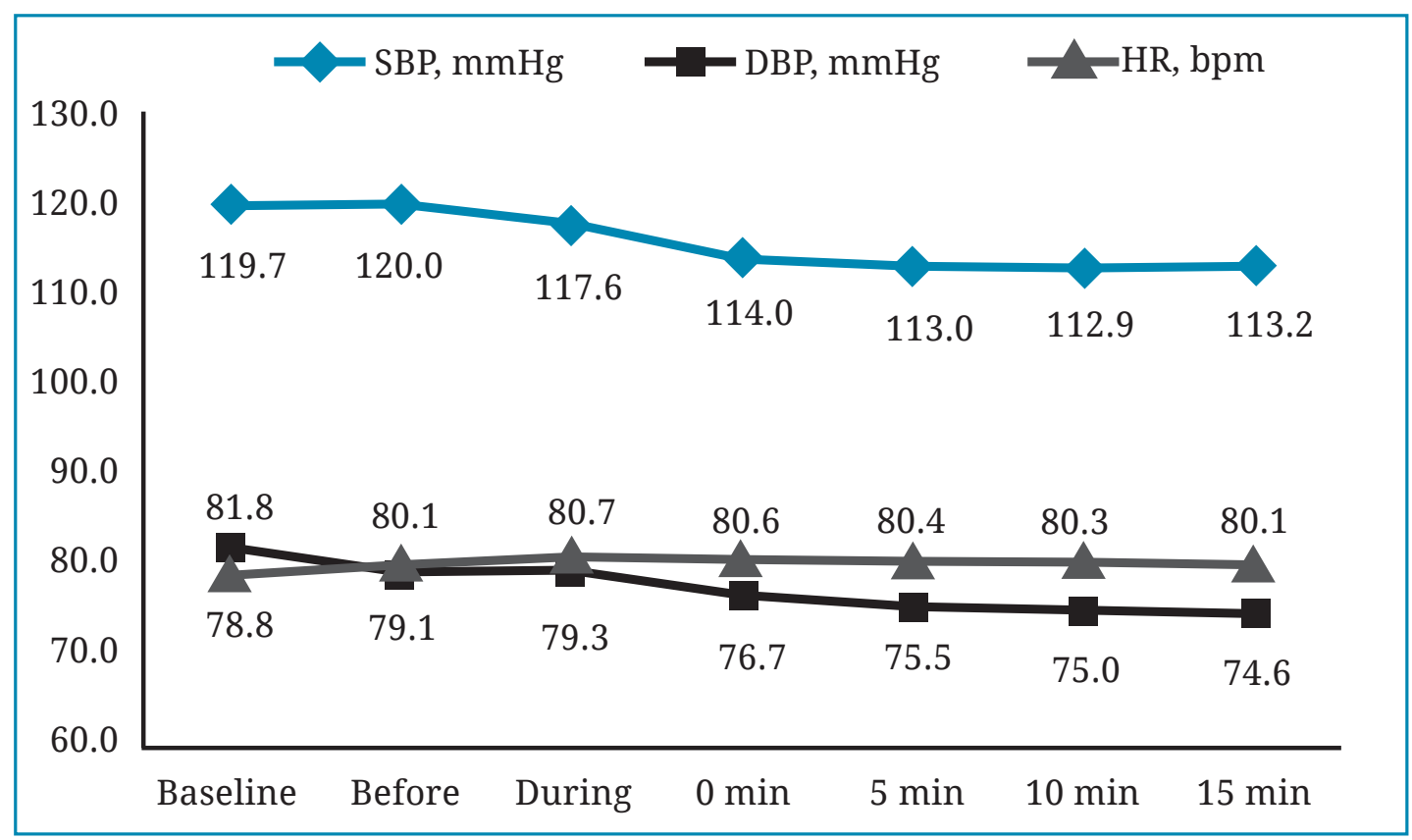

Fig. 2: Distribution of donors in different experimental groups $(\mathrm{N}=448)(\mathrm{PW}=$ plain water, $\mathrm{ORS}=$ oral rehydration solution, $\mathrm{FJ}=$ fruit juice, $\mathrm{AMT}=$ active muscle tension) 


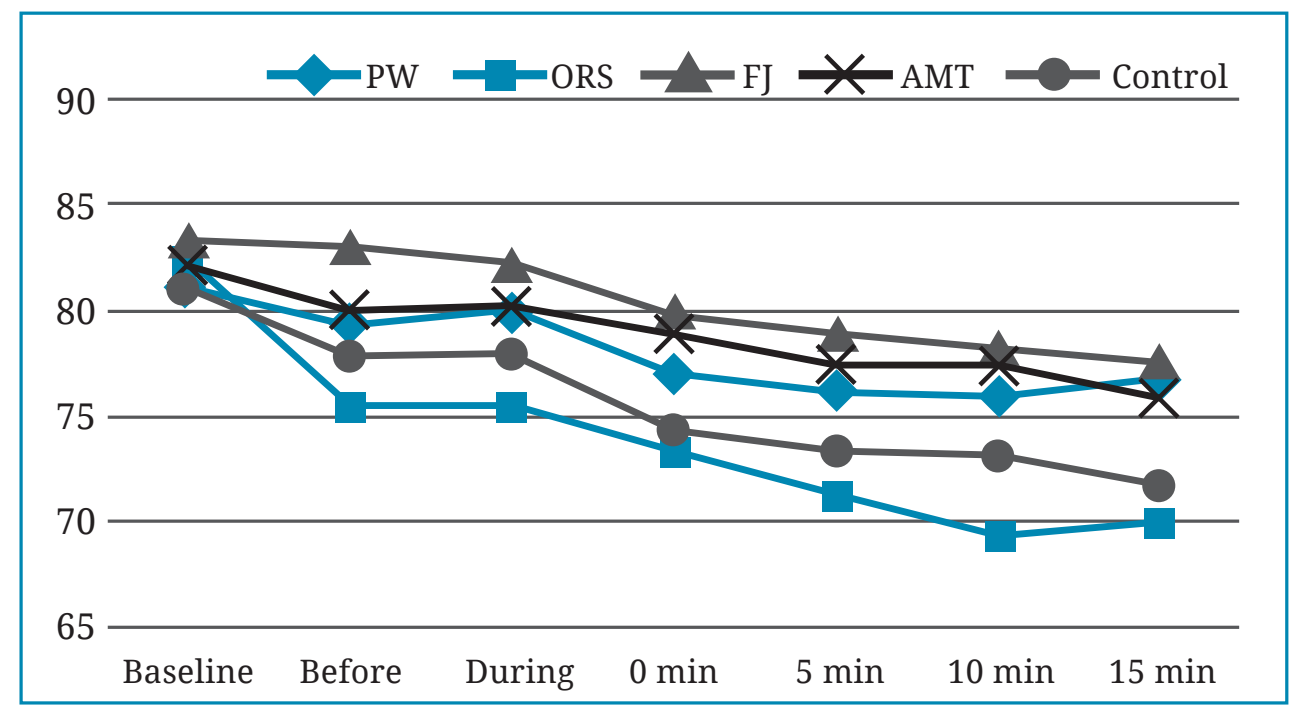

Fig. 3: Systolic blood pressure ( $\mathrm{mmHg}$ ) change in different donor groups

\begin{tabular}{|c|c|c|c|c|c|c|c|c|}
\hline \multicolumn{2}{|c|}{ Characteristics } & \multirow{3}{*}{$\begin{array}{c}\begin{array}{c}\text { PW } \\
(\mathbf{n}=97)\end{array} \\
80(82.5) \\
17(17.5)\end{array}$} & \multirow{3}{*}{$\begin{array}{c}\begin{array}{c}\text { ORS } \\
(n=71)\end{array} \\
61(85.7) \\
10(14.3)\end{array}$} & \multirow{3}{*}{$\begin{array}{c}\begin{array}{c}\text { FJ } \\
(\mathbf{n}=74)\end{array} \\
65(87.7) \\
9(12.3)\end{array}$} & \multirow{3}{*}{$\begin{array}{c}\begin{array}{c}\text { AMT } \\
(\mathbf{n}=91)\end{array} \\
85(93.4) \\
6(6.6)\end{array}$} & \multirow{3}{*}{$\begin{array}{c}\text { Control } \\
(\mathbf{n}=115)\end{array}$} & \multirow{3}{*}{$\begin{array}{c}\begin{array}{c}\text { Total } \\
(\mathrm{N}=448)\end{array} \\
388(86.6) \\
60(13.4)\end{array}$} & \multirow{3}{*}{$\begin{array}{c}\begin{array}{c}\text { P value } \\
\text { ( } \chi^{2} \text { or } \\
\text { ANOVA) }\end{array} \\
0.224\end{array}$} \\
\hline \multirow{2}{*}{$\begin{array}{l}\text { Gender } \\
\text { distribution }\end{array}$} & Male (\%) & & & & & & & \\
\hline & Female (\%) & & & & & & & \\
\hline \multirow{2}{*}{$\begin{array}{l}\text { Age } \\
\text { (completed } \\
\text { years) }\end{array}$} & Mean & 29.35 & 28.39 & 30.55 & 28.69 & 30.10 & 29.42 & \multirow{2}{*}{0.741} \\
\hline & SD & 8.05 & 7.92 & 6.434 & 6.58 & 8.81 & 1.66 & \\
\hline \multirow{2}{*}{ Height (cms) } & Mean & 1.64 & 1.67 & 1.65 & 1.67 & 1.66 & 1.66 & \multirow{2}{*}{0.123} \\
\hline & SD & 0.09 & 0.08 & 0.07 & 0.06 & 0.09 & 0.08 & \\
\hline \multirow{2}{*}{ Weight (kg) } & Mean & 67.00 & 67.72 & 67.97 & 67.83 & 66.79 & 67.4 & \multirow{2}{*}{0.785} \\
\hline & SD & 8.71 & 9.71 & 10.02 & 9.65 & 10.74 & 9.74 & \\
\hline \multirow{2}{*}{ BMI (kg/m²) } & Mean & 24.85 & 24.03 & 25.13 & 24.75 & 24.48 & 24.68 & \multirow{2}{*}{0.391} \\
\hline & SD & 3.10 & 2.70 & 3.36 & 3.10 & 3.43 & 3.17 & \\
\hline \multicolumn{2}{|c|}{$\begin{array}{l}\text { Number of donations in the } \\
\text { past for most donors (mode) }\end{array}$} & 1 & 1 & 1 & 0 & 1 & 1 & \\
\hline
\end{tabular}

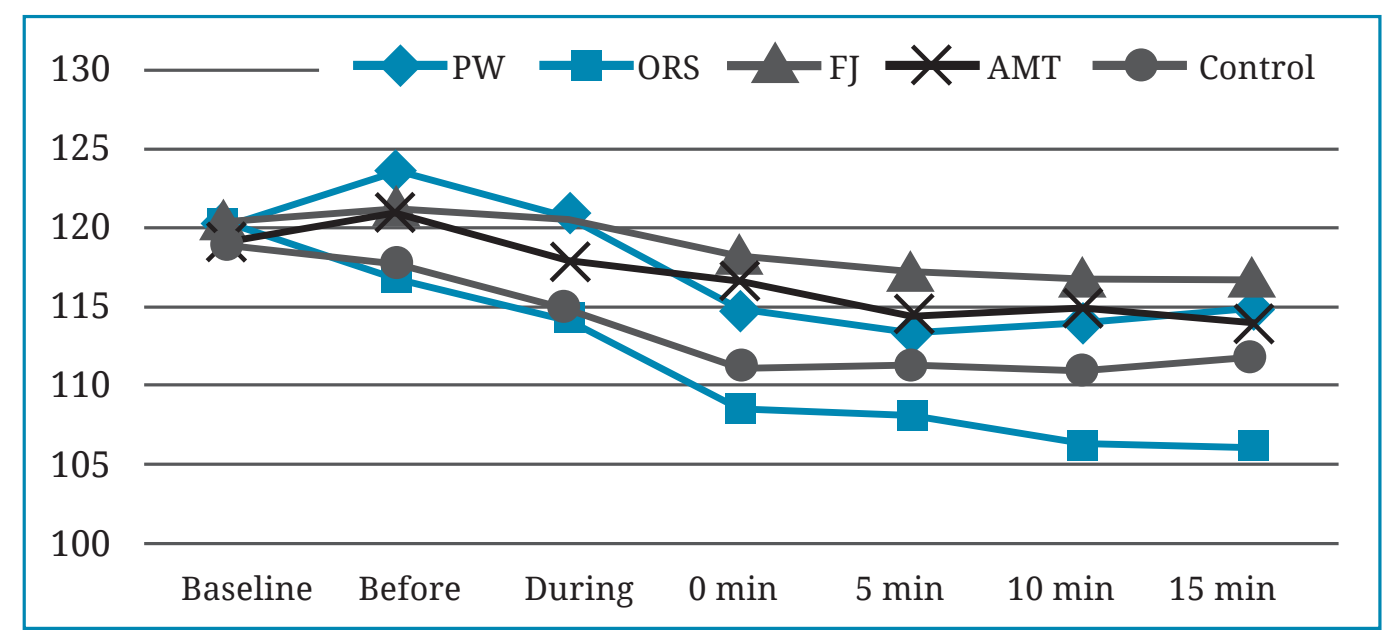

Fig. 4: Diastolic blood pressure (mmm Hg) change in different donot groups 
Table 2: Comparison of blood pressures and heart rate at the time of recruitment (baseline values)

\begin{tabular}{|lccccccc|} 
Parameters & PW & ORS & FJ & AMT & Control & \multicolumn{2}{c|}{ ANOVA } \\
& & & & & & \\
F value & P value \\
$( \pm$ SD $)$ & 120.02 & 119.97 & 120.29 & 119.21 & 118.95 & \multirow{2}{*}{0.320} & 0.865 \\
DBP, mmHg & $( \pm 9.95)$ & $( \pm 8.89)$ & $( \pm 9.16)$ & $( \pm 9.21)$ & $( \pm 8.65)$ & & \\
$( \pm$ SD $)$ & $( \pm 8.49)$ & 82.29 & 83.37 & 82.0 & 80.76 & 1.850 & 0.119 \\
HR, bpm $* * *$ & 77.51 & $76.65)$ & $( \pm 5.19)$ & $( \pm 5.36)$ & $( \pm 7.14)$ & & \\
$( \pm$ SD $)$ & $( \pm 11.23)$ & $( \pm 8.45)$ & $( \pm 7.7)$ & $( \pm 2.84)$ & $( \pm 6.75)$ & 9.034 & 0.000 \\
\hline
\end{tabular}

Table 3: Hemodynamic response to blood donation in different donor groups

\begin{tabular}{|c|c|c|c|c|c|c|c|c|}
\hline Parameter & $\begin{array}{l}\text { Donor } \\
\text { groups }\end{array}$ & Before & During & $0 \mathrm{~min}$ & $5 \mathrm{~min}$ & $10 \mathrm{~min}$ & $15 \mathrm{~min}$ & $\begin{array}{c}\text { P value } \\
\text { (repeated } \\
\text { measures } \\
\text { ANOVA) }\end{array}$ \\
\hline \multirow{5}{*}{$\begin{array}{l}\text { SBP, mmHg } \\
( \pm \text { SD) }\end{array}$} & PW & $\begin{array}{l}125.48 \\
\pm 14.92\end{array}$ & $\begin{array}{l}122.76 \\
\pm 14.57\end{array}$ & $\begin{array}{l}116.56 \\
\pm 16.66\end{array}$ & $\begin{array}{l}115.95 \\
\pm 16.68\end{array}$ & $\begin{array}{l}116.43 \\
\pm 15.45\end{array}$ & $\begin{array}{l}117.37 \\
\pm 15.44\end{array}$ & \multirow{5}{*}{0.000} \\
\hline & ORS & $\begin{array}{l}117.83 \\
\pm 12.12\end{array}$ & $\begin{array}{l}113.89 \\
\pm 14.34\end{array}$ & $\begin{array}{c}108.2 \\
\pm 16.31\end{array}$ & $\begin{array}{l}108.39 \\
\pm 13.83\end{array}$ & $\begin{array}{l}105.96 \\
\pm 14.11\end{array}$ & $\begin{array}{l}106.07 \\
\pm 12.43\end{array}$ & \\
\hline & $\mathbf{F J}$ & $\begin{array}{c}121.34 \\
\pm 8.69\end{array}$ & $\begin{array}{l}120.69 \\
\pm 10.21\end{array}$ & $\begin{array}{l}118.0 \\
\pm 8.77\end{array}$ & $\begin{array}{l}116.96 \\
\pm 10.46\end{array}$ & $\begin{array}{l}116.72 \\
\pm 11.18\end{array}$ & $\begin{array}{l}116.69 \\
\pm 11.12\end{array}$ & \\
\hline & AMT & $\begin{array}{l}120.55 \\
\pm 10.67\end{array}$ & $\begin{array}{l}117.43 \\
\pm 12.39\end{array}$ & $\begin{array}{l}116.02 \\
\pm 12.44\end{array}$ & $\begin{array}{l}113.93 \\
\pm 13.55\end{array}$ & $\begin{array}{l}114.42 \\
\pm 11.24\end{array}$ & $\begin{array}{l}114.15 \\
\pm 11.18\end{array}$ & \\
\hline & Control & $\begin{array}{c}117.9 \\
\pm 10.19\end{array}$ & $\begin{array}{l}114.52 \\
\pm 9.13\end{array}$ & $\begin{array}{l}110.23 \\
\pm 13.41\end{array}$ & $\begin{array}{l}110.96 \\
\pm 11.11\end{array}$ & $\begin{array}{c}110.92 \\
\pm 11.9\end{array}$ & $\begin{array}{c}111.9 \\
\pm 11.33\end{array}$ & \\
\hline \multirow{5}{*}{$\begin{array}{l}\text { DBP, mmHg } \\
( \pm \text { SD) }\end{array}$} & PW & $\begin{array}{c}80.32 \\
\pm 11.73\end{array}$ & $\begin{array}{c}81.29 \\
\pm 12.86\end{array}$ & $\begin{array}{l}77.81 \\
\pm 14.4\end{array}$ & $\begin{array}{c}77.02 \\
\pm 15.49\end{array}$ & $\begin{array}{l}77.08 \\
\pm 12.5\end{array}$ & $\begin{array}{c}77.54 \\
\pm 13.51\end{array}$ & \multirow{5}{*}{0.000} \\
\hline & ORS & $\begin{array}{l}75.65 \\
\pm 9.66\end{array}$ & $\begin{array}{l}75.78 \\
\pm 9.91\end{array}$ & $\begin{array}{c}72.96 \\
\pm 12.12\end{array}$ & $\begin{array}{r}71.46 \\
\pm 12.75\end{array}$ & $\begin{array}{c}69.02 \\
\pm 10.83\end{array}$ & $\begin{array}{c}70.43 \\
\pm 10.68\end{array}$ & \\
\hline & FJ & $\begin{array}{l}83.03 \\
\pm 5.25\end{array}$ & $\begin{array}{l}82.12 \\
\pm 7.75\end{array}$ & $\begin{array}{l}79.82 \\
\pm 6.77\end{array}$ & $\begin{array}{l}78.73 \\
\pm 7.51\end{array}$ & $\begin{array}{c}78.0 \\
\pm 9.39\end{array}$ & $\begin{array}{l}77.48 \\
\pm 7.4\end{array}$ & \\
\hline & AMT & $\begin{array}{l}79.65 \\
\pm 8.81\end{array}$ & $\begin{array}{l}79.47 \\
\pm 9.89\end{array}$ & $\begin{array}{c}78.73 \\
\pm 11.25\end{array}$ & $\begin{array}{r}77.19 \\
\pm 11.45\end{array}$ & $\begin{array}{c}76.96 \\
\pm 10.19\end{array}$ & $\begin{array}{c}76.23 \\
\pm 10.84\end{array}$ & \\
\hline & Control & $\begin{array}{l}77.9 \\
\pm 9.5\end{array}$ & $\begin{array}{l}77.58 \\
\pm 9.13\end{array}$ & $\begin{array}{c}73.27 \\
\pm 10.96\end{array}$ & $\begin{array}{l}72.18 \\
\pm 9.77\end{array}$ & $\begin{array}{l}72.73 \\
\pm 9.38\end{array}$ & $\begin{array}{c}71.9 \\
\pm 9.29\end{array}$ & \\
\hline \multirow{5}{*}{$\begin{array}{l}\text { HR, bpm } \\
( \pm \text { SD) }\end{array}$} & PW & $\begin{array}{c}77.6 \\
\pm 9.78\end{array}$ & $\begin{array}{c}78.7 \\
\pm 9.64\end{array}$ & $\begin{array}{l}78.59 \\
\pm 8.95\end{array}$ & $\begin{array}{l}79.29 \\
\pm 8.54\end{array}$ & $\begin{array}{l}79.06 \\
\pm 8.26\end{array}$ & $\begin{array}{l}78.84 \\
\pm 8.31\end{array}$ & \multirow{5}{*}{0.000} \\
\hline & ORS & $\begin{array}{l}78.76 \\
\pm 7.15\end{array}$ & $\begin{array}{l}80.49 \\
\pm 5.97\end{array}$ & $\begin{array}{l}82.53 \\
\pm 7.12\end{array}$ & $\begin{array}{l}82.13 \\
\pm 8.99\end{array}$ & $\begin{array}{l}82.31 \\
\pm 9.29\end{array}$ & $\begin{array}{l}81.64 \\
\pm 7.95\end{array}$ & \\
\hline & $\mathbf{F J}$ & $\begin{array}{l}81.72 \\
\pm 7.53\end{array}$ & $\begin{array}{l}81.51 \\
\pm 6.91\end{array}$ & $\begin{array}{c}81.17 \\
\pm 8.0\end{array}$ & $\begin{array}{l}80.54 \\
\pm 7.43\end{array}$ & $\begin{array}{l}80.22 \\
\pm 7.58\end{array}$ & $\begin{array}{l}80.18 \\
\pm 6.81\end{array}$ & \\
\hline & AMT & $\begin{array}{c}83.35 \\
\pm 10.62\end{array}$ & $\begin{array}{l}83.43 \\
\pm 8.59\end{array}$ & $\begin{array}{c}82.87 \\
\pm 7.7\end{array}$ & $\begin{array}{l}81.43 \\
\pm 6.86\end{array}$ & $\begin{array}{l}80.75 \\
\pm 5.72\end{array}$ & $\begin{array}{l}80.15 \\
\pm 6.05\end{array}$ & \\
\hline & Control & $\begin{array}{l}79.31 \\
\pm 5.96\end{array}$ & $\begin{array}{l}80.56 \\
\pm 5.88\end{array}$ & $\begin{array}{l}79.92 \\
\pm 6.02\end{array}$ & $\begin{array}{l}80.27 \\
\pm 6.19\end{array}$ & $\begin{array}{c}80.45 \\
\pm 5.3\end{array}$ & $\begin{array}{l}80.19 \\
\pm 5.04\end{array}$ & \\
\hline
\end{tabular}


Table 4: Adverse effects in different donor groups

\begin{tabular}{lccccccc|}
$\begin{array}{l}\text { Types of } \\
\text { adverse effect }\end{array}$ & $\begin{array}{c}\text { PW } \\
(\mathbf{n}=\mathbf{9 7})\end{array}$ & $\begin{array}{c}\text { ORS } \\
(\mathbf{n}=71)\end{array}$ & $\begin{array}{c}\text { FJ } \\
(\mathbf{n}=74)\end{array}$ & $\begin{array}{c}\text { AMT } \\
\mathbf{( n = 9 1 )}\end{array}$ & $\begin{array}{c}\text { Control } \\
(\mathbf{n}=115)\end{array}$ & $\begin{array}{c}\text { Total } \\
(\mathbf{N}=\mathbf{4 4 8})\end{array}$ & $\begin{array}{c}\text { P value } \\
\text { (Chi squared) }\end{array}$ \\
Subjective & $5(5.2 \%)$ & $3(4.2 \%)$ & $2(2.7 \%)$ & $3(3.3 \%)$ & $3(2.6 \%)$ & $16(3.6 \%)$ & 0.864 \\
$\begin{array}{l}\text { Presyncope } \\
\text { Syncope }\end{array}$ & $8(8.2 \%)$ & $5(7.0 \%)$ & $2(2.7 \%)$ & $4(4.4 \%)$ & $2(1.7 \%)$ & $21(4.7 \%)$ & 0.162 \\
$\begin{array}{l}\text { Number } \\
\text { of donors } \\
\text { having AE }\end{array}$ & $3(3.1 \%)$ & $1(1.4 \%)$ & 0 & $1(1.1 \%)$ & $2(1.7 \%)$ & $7(1.6 \%)$ & 0.590 \\
\hline
\end{tabular}

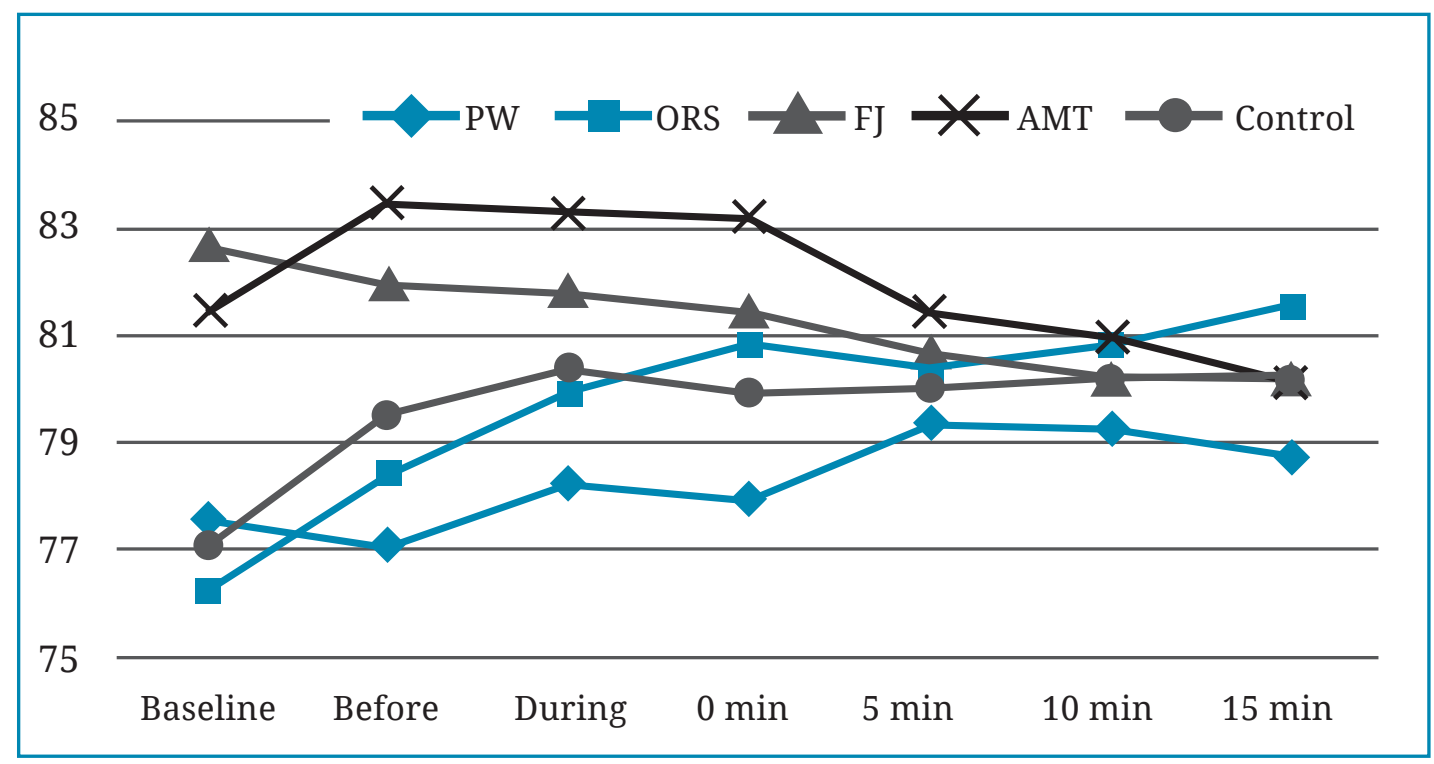

Fig.5: Heart rate (bpm) changes in different donor groups

subjectively by the donors were light-headedness, dizziness, blackout, hot flushes, uneasiness, and cramping of legs. Of the total 448 donors, 35 donors (7.8\%) suffered $\mathrm{AE}$ and some had more than one type of AE. Presyncope was the most common type of AE. The FJ and Control groups had least percentage of donors experiencing $\mathrm{AE}$ while the PW group had the highest percentage, ORS being the group with second highest percentage of donors with AE (Table 4). There was highest group difference for presyncope. The incidence rate for presyncope was highest in the PW and lowest in the Controls, the difference was statistically significant $(p<0.05$, Chi squared). The incidence of subjective AE differed least among groups. There was no occurrence of syncope in the FJ group. All other differences were found insignificant. Overall, the $\mathrm{AE}$ correlated significantly with each other. The correlation coefficient (Spearman's rho) between subjective $\mathrm{AE}$ and presyncope was $0.128(\mathrm{p}=0.007)$, between subjective $\mathrm{AE}$ and syncope was $0.364(\mathrm{p}=0.000)$ and between presyncope and syncope was 0.313 $(\mathrm{p}=0.001)$.

\section{DISCUSSION}

The importance of blood donation as a key component of modern health care system is established. One major and common factor detering eligible donors from the blood donation practice is the occurrence of adverse effects which result from the challenge of acute blood loss in the process. ${ }^{3,4,12}$

This study compared some of the approaches aimed at reducing severity or preventing adverse effects in blood donors against a control group. In the 448 Nepalese donors, the overall incidence of $\mathrm{AE}$ was $7.8 \%$ and included subjective adverse experiences, clinically diagnosed presyncope, and syncope. Most studies have reported lower incidences $\mathrm{AE}$, from 1.1 to $2.5 \% \cdot{ }^{1,13-15}$ One study has reported an incidence rate of $\mathrm{AE} \mathrm{(6.07 \% )}$ 
closer to finding of this study. ${ }^{16}$ Various factors are associated with the risk of developing AE such as age, sex, donation status, and body weight. ${ }^{2}$ As a result, even in the same environment, variations in $\mathrm{AE}$ rates are observed. For example, in a large scale study in the United States by Eder et al, blood donation was complicated with $\mathrm{AE}$ in $10.7 \%$ in young donors (16-17 years), 8.3\% in 18-19 years, and only $2.8 \%$ in 20 years or older donors. ${ }^{3}$

This study defined presyncope and syncope as clinically diagnosed entities while in most studies these conditions were labeled based on donors' complaints and subjective observations. Many donors do not have complaints despite having marked hemodynamic changes. This could be the reason for the overall high rate of $\mathrm{AE}$ in this study. The $2.6 \%$ occurrence of subjective $\mathrm{AE}$ in the Controls is comparable to the report by Agnihotri et al (2012). ${ }^{15}$ Moreover, all the experimental donor groups had higher rates of AE compared to the Controls, except for the FJ group who had almost similar rates of subjective $\mathrm{AE}$ and presyncope.

Leg crossing and muscle tensing is known to increase BP in supine as well as free standing position, by the mechanism of increasing cardiac output via sympathetic activation. The maneuver has been used with benefits in hypotensive states such as orthostatic hyptension. ${ }^{17-19}$ The use of the technique to blood donors has been reported to bear significantly beneficial effects. ${ }^{20,21}$ In this study, the muscle tensing exercise did not result in significant differences compared to Control. BP and HR lowered slightly during blood removal and more in the post-donation period. The later decrease may be due to removal of the cardiostimulatory effects of sympathetic activation as soon as the exercise was stopped with completion of blood removal.

Water ingestion has a potent pressor response in healthy individuals as well as patients of autonomic failure, probably by a sympathetic reflex mechanism..$^{22,23}$ This is beneficial as prophylaxis against syncope associated with orthostatic hypotension. ${ }^{5}$ Hanson and France (2004) have reported a $47 \%$ reduction in total donation-related symptoms in blood donors with water prehydration as compared to controls in a study comprising 83 first time donors. ${ }^{24}$ However, one randomized clinical trial conducted in South Africa $(n=2,464)$ did not find differences in presyncope and syncope in blood donors having water prehydration against donors without prehydration. ${ }^{6}$ Other types of fluid than plain water have been used infrequently. One study has reported significantly less occurrence of vasovagal (syncopal) reactions by prehydration with 250 $\mathrm{mL}$ salt water (lemon flavored, sweetened) as compared to placebo ( $250 \mathrm{~mL}$ plain water). ${ }^{25}$ The pattern of fall in SBP as well as DBP in this study during and after blood removal is not suggestive of any beneficial effect, especially in the PW and ORS groups. The groups also had higher rates of adverse effects compared to Control group.

When prehydration was combined with leg exercises, presyncopal reactions were found to be significantly attenuated in novice donors as compared to prehydration alone or no intervention. ${ }^{26}$ It is usual practice by donors to consume fruit juice after blood donation, during recovery or rest period. Banana isotonic drink (500 mL) was shown to improve orthostatic tolerance in voluntary dehydration subjects. ${ }^{11}$ Fruit juice prehydration in blood donors has not been reported.

Conclusion: This study showed that the prehydration with different fluids or leg muscle tensing during blood donation were not effective in prevention or attenuation of $\mathrm{AE}$ in blood donors. However, this study defined vasovagal adverse effects (presyncope and syncope) based on hemodynamic physiological parameters, which is in contrast to other studies based on subjective or symptomatic AE. In this regard, prehydration with plain water or oral rehydration solution seemed to pose a risk of more falls in BP and HR in donors, which could provoke symptomatic syncope. Additionally, the immediate effects of fluid ingestion may also have impact in the hemodynamics of donors. More controlled studies should be conducted to verify the findings. The time-related effects of oral intake of different fluids also needs exploration.

\section{ACKNOWLEDGEMENT}

The kind permission by the Central Blood Transfusion Services, Exhibition Road, Kathmandu to conduct this study in its premises is highly appreciated. The author is also thankful to Mr. Ram Krishna Tamang (Department of Community Medicine, Nepal Medical College, Kathmandu) for his help with statistical analysis. 


\section{REFERENCES}

1. Crocco A, D’Elia D. Adverse reactions during voluntary donation of blood and/or blood components. A statistical-epidemiological study. Blood Transfus 2007; 5: 143-52. DOI: 10.2450/2007.0005-07

2. Philip J, Sarkar RS, Jain N. A single-centre study of vasovagal reaction in blood donors: Influence of age, sex, donation status, weight, total blood volume and volume of blood collected. Asian J Transfus Sci 2014; 8: 43-6. DOI: 10.4103/0973-6247.126690

3. Eder AF, Hillyer CD, Dy BA, Dy BA. Adverse reactions to allogeneic whole blood donation by 16- and 17-year-olds. J Am Med Assoc 2008; 299: 2279-86. DOI: 10.1001/jama.299.19.2279

4. Custer B, Rios JA, Schlumpf K, Kakaiya RM, Gottschall JL, Wright DJ. Adverse reactions and other factors that impact subsequent blood donation visits. Transfusion 2012; 52: 118-26. DOI: 10.1111/j.1537-2995.2011.03216.x.

5. Lu C, Diedrich A, Tung C, Paranjape SY, Harris PA, Byrne DW, et al. Water ingestion as prophylaxis against syncope. Circulation 2003; 108: 2660-5. DOI: 10.1161/01.CIR.0000101966.24899.CB

6. Berg K van den, Lam J, Bruhn R, Custer B, Murphy EL. Water administratin and the risk of syncope and pre-syncope during blood donation: a randomized clinical trial. Transfusion 2012; 52: 2577-84. DOI: 10.1111/j.1537-2995.2012.03631.x.Water

7. Ditto B, Wilkins J, France CR, Lavoie P, Adler PSJ. On-site training in applied muscle tension to reduce vasovagal reactions to blood donation. J Behav Med 2003; 26: 53-65. DOI: 10.1023/a:1021795022380

8. Holly CD, Torbit L, Ditto B. Applied tension and coping with blood donation : a randomized trial. Ann Behav Med 2012; 43: 173-80. DOI: 10.1007/ s12160-011-9315-8

9. Figueroa JJ, Basford JR, Low PA. Preventing and treating orthostatic hypotension : as easy as A, B , C. Cleve Clin J Med 2010; 77: 298-306. DOI: 10.3949/ ccjm.77a.09118

10. Mendonca GV, Teixeira MS, Heffernan KS, Fernhall B. Chronotropic and pressor effects of water ingestion at rest and in response to incremental dynamic exercise. Exp Physiol 2013; 6: 1133-43. DOI: 10.1113/expphysiol.2013.071886

11. Penggalih M, Gardjito M, Sofro Z. Banana isotonic drink improves orthostatic tolerance in voluntary dehydration subject. Int'l Food Res J 2012; 19: 883-7.

12. Amatya M. Study on knowledge, attitude and practice of blood donation among students of different colleges of Kathmandu, Nepal. Int'l J Pharm Biol Arch 2013; 4: 424-8. Available from: http://www.ijpba.info/ijpba/index.php/ijpba/ article/view/1003/689

13. Rathod K, Chudhury M. Study of adverse events and predisposing factors in whole blood donors at a tertiary care hospital. Int'l J Adv Res 2014; 2: 1148-53.

14. John CA, Theodora UE, Gloria AN, Chika EA. Adverse reactions to blood donation: A descriptive study of 3520 blood donors in a Nigerian tertiary hospital. Med J Dr DY Patil Univ 2017; 10: 36. DOI: 10.4103/0975-2870.197894

15. Agnihotri N, Marwaha N, Sharma RR. Analysis of adverse events and predisposing factors in voluntary and replacement whole blood donors: A study from north India. Asian J Transfus Sci 2012; 6: 155-60. DOI: 10.4103/0973-6247.98922

16. Bhardwaj K, Bassi R, Singh M, Singal P, Sharma A, Bhardwaj H. Adverse donor reactions in whole blood and blood component donors of a tertiary care hospital of Punjab, India. Res J Pharm Biol Chem Sci 2014; 5: 306-13.

17. Van Dijk N, De Bruin IGJM, Gisolf J et al. Hemodynamic effects of leg crossing and skeletal muscle tensing during free standing in patients with vasovagal syncope. J Appl Physiol 2005; 98: 584-90. DOI: 10.1152/japplphysiol.00738.2004

18. Van Groningen LFJ, Adiyaman A, Elving L, Thien T, Lenders JWM, Deinum J. Which physiological mechanism is responsible for the increase in blood pressure during leg crossing? J Hypertens 2008; 26: 433-7. DOI: 10.1097/HJH.0b013e3282f35276

19. Groothuis JT, Van Dijk N, Ter Woerds W, Wieling W, Hopman MTE. Leg crossing with muscle tensing, a physical counter-manoeuvre to prevent syncope, enhances leg blood flow. Clin Sci 2007; 112: 193201. DOI: $10.1042 / C S 20060241$

20. Ditto B, France CR, Albert M, Byrne N. Dismantling applied tension: mechanisms of a treatment to reeduce blood donation-related symptoms. Transfusion 2007; 47: 2217-22. DOI: 10.1111/j.15372995.2007.01449.x

21. Holly CD. Anxiety, applied tension, and vasovagal symptoms in blood donors. McGill University, Quebec, Canada; 2011.

22. Cariga P, Mathias CJ. Haemodynamics of the pressor effect of oral water in human sympathetic denervation due to autonomic failure. Clin Sci 2001; 101: 313-9. Available from: http://www.clinsci.org/ content/ppclinsci/101/3/313.full.pdf

23. Jordan J, Shannon JR, Grogan E, Biaggioni I, Robertson D. A potent pressor response elicited by drinking water. Lancet 1999; 353: 726. DOI: 10.1016/S0140-6736(99)99015-3

24. Hanson SA, France CR. Predonation water ingestion attenuates negative reactions to blood donation. Transfusion 2004; 44: 924-8. DOI: 10.1111/j.15372995.2004.03426.x

25. Sachdev S, Singh L, Sharma RR, Marwaha N. A Study on the Effect of Pre-donation Salt Loading on Vasovagal Reactions in Young College Going Whole Blood Donors. Indian J Hematol Blood Transfus 2017; 33: 592-7. DOI: 10.1007/s12288-017-0787-y

26. France CR, Ditto B, Wissel ME, France JL, Dickert T, Rader A, et al. Pre-donation hydration and appliedd muscle tension combine to reduce presyncopal reactions to blood donation. Transfusion 2010; 50: 1257-64. DOI: 10.1111/j.1537-2995.2009.02574.x. 